Canadian Studies in Population, Vol. 32.1, 2005, pp. 1-28

\title{
Panethnicity and Ethnic Resources in Residential Integration: A Comparative Study of Two Host Societies
}

\author{
Ann H. Kim \\ Department of Sociology \\ Population Studies and Training Center \\ Brown University \\ Boston, Massachusetts
}

\begin{abstract}
The racial and ethnic structure of a host society as well as its institutional and ideological context of integration shape the ethnic integration process. To examine these forces for residential integration, this study compares three panethnic groups in Canada and the United States using tabular data from the 2001 Canadian and the 2000 US censuses. Two ways in which the social context is important are identified. First, the social context affects how groups are distributed across urban neighbourhoods. As expected, being a Black ethnic group meant being less segregated in Canada than in the US but Asian groups were more segregated, controlling for group characteristics and the urban and regional context. White ethnic groups in both countries were similarly segregated. Second, the social context influences the process of incorporation itself. The effect of ethnic resources, in terms of acculturation and socioeconomic status, was dependent on the group and host society. The results demonstrate that the national context plays a significant role in the way panethnic group membership influences the spatial processes of ethnic groups in the urban neighbourhoods of the two host societies.
\end{abstract}

Key Words: Residential segregation, ethnic integration, panethnicity 
Ann H. Kim

\section{Résumé:}

La structure raciale et ethnique d'une société d'accueil et son contexte institutionnel et idéologique d'intégration forment le processus d'intégration ethnique. Dans le but d'examiner l'impact de ces éléments dans l'intégration résidentielle, cette étude compare trois groupes panethniques au Canada et aux États-Unis en s'appuyant sur les données tabulaires du recensement canadien de 2001 et du recensement américain de 2000. L'importance du contexte social a été mesurée de deux façons : D'abord, le contexte social affecte la distribution des groupes dans les quartiers urbains. Comme on pouvait s'y attendre, appartenir à un groupe ethnique noir se traduit par une ségrégation moindre au Canada qu'aux États-Unis mais pas pour les groupes asiatiques qui connaissent une ségrégation plus élevée; une fois les ressources de groupes et le contexte urbain et régional pris en considération. Les groupes ethniques blancs des deux pays connaissent des niveaux de ségrégation similaires. Deuxièmement, le contexte social influence le processus d'incorporation même. L'effet des ressources ethniques, en termes d'acculturation et de statut socio-économique, dépendait des groupes et des sociétés d'accueil. Les résultats démontrent que le contexte national joue un rôle important dans la manière avec laquelle l'appartenance à un groupe panethnique influence les processus spatiaux des groupes ethniques dans les quartiers urbains des deux sociétés d'accueil.

Mots clés : La ségrégation résidentielle, l'intégration ethnique, la panethnicité.

\section{Introduction}

The ethnic integration process is embedded in a larger institutional and ideological milieu and this has implications for residential patterns. Comparative studies of ethnic groups in different locations reveal that ethnic incorporation is linked to contextual forces in host societies (Bloemraad 2003; Dinardo and Lemieux 1997; Lewin-Epstein et al. 2003; Model 1997; Reitz 1998). In terms of the residential integration process, ethnic groups are faced with a unique racial or ethnic structure in which residential decisions are made and the degree of concentration is a form of adjustment to local and national conditions that either encourage or discourage clustering for a given group. 
Panethnicity and Ethnic Resources in Residential Integration:

A Comparative Study of Two Host Societies

In this study, comparison is made of ethnic residential segregation in two host societies, Canada and the United States. The effect of ethnic resources and the influence of panethnic group membership on residential patterns is looked at specifically. Two dimensions of ethnic resources are highlighted, acculturation and socio-economic resources, and in examining their effects, paths to residential incorporation are identified and compared across contexts. For both countries, fourteen ethnic origin groups are included in the analysis and each is classified into one of the three panethnic groupings, Asian, Black or White. The term panethnic grouping is used to refer to more encompassing ethnic boundaries that extend beyond national origins and includes those groups perceived to share some structural or cultural traits. There is some degree of conceptual overlap between panethnicity and race as racial traits can be shared among panethnic group members, however, panethnicity is the preferred concept as it recognizes the layering of social identities, and ethnic and cultural diversity within constructed boundaries. By contrasting these panethnic groupings across different host societies, one can illustrate the importance of context in ethnic integration.

\section{Past Studies of Residential Segregation}

The study of the geographic concentration of ethnic groups in urban areas has a long history in both Canada and the United States. Members of immigrant communities often congregate in particular neighbourhoods to be near kith and kin or as a result of inaccessibility to other residential areas. The empirical study of residential patterns within urban areas demonstrates the persistent separation of ethnic groups even over generations in both countries (Balakrishnan and Gyimah 2003; Guest and Weed 1976; Kalbach 1990; Kantrowitz 1973; Lieberson 1963). Analyses of segregation among a range of national origin groups and across panethnic or racial groups reveal moderate to high levels (White, Fong and Cai 2003; White, Kim and Glick Forthcoming; Zhou and Logan 1991).

Studies that compared segregation patterns across the two countries have revealed some interesting contrasts. Blacks in the US were more segregated than Asians while in Canada, Blacks and Asians were similarly positioned on segregation measures (Fong 1996). In a more recent analysis, higher levels of segregation, in general, were also found in the US (White, Fong and Cai 2003). The processes underlying segregation patterns also differed between the two countries. Although the urban context was important for both places, the effects of particular dimensions differed in degree and varied by group. There were also differences in the direction of effects for other urban variables. These studies suggest that current residential patterns not only differ across ethnic and racial 
groups but across contexts. Yet, they are limited in the range of included groups and for understanding both group and contextual influences on residential processes. Reception in the host society, the diversity of group characteristics and the history of urban settlement engender alternate trajectories of integration. These factors underscore the need for more comparative work.

\section{Conceptual Framework}

Three perspectives have been used to explain observed patterns of residential integration, spatial assimilation, place stratification and ethnic retention. The theory of spatial assimilation, derived from the work of Robert E. Park and Ernest Burgess of the Chicago School, explains the process of adaptation by newcomers to a host society (Park, Burgess and McKenzie 1925). Under this perspective, it is expected that newcomers initially live and work within their own ethnic communities but over time, as they acculturate and improve their economic standing they reach social parity with the dominant group. Explicit in this definition of social parity is spatial propinquity as residential dispersion from ethnic neighbourhoods should be concomitant to rising economic resources and exposure to the host society (Massey and Mullan 1984). Differential locational distributions of racial and ethnic groups are then explained by differences in socio-economic resources and length of residence.

This theory developed in the context of European immigration with White ethnic groups and has had an immense influence on contemporary studies of residential settlement as spatial assimilation is perceived to be a "necessary intermediate step" in the general assimilation process (Massey and Mullan 1984). However, this perspective has been criticized for its assumption of a straight-line path to assimilation, which has not been substantiated (Balakrishnan 2001; Fong and Wilkes 1999; Kalbach 1990; White, Fong and Cai 2003; White and Sassler 2000). In the United States, spatial assimilation theory has been generally supported by the experience of Whites and of Latinos and Asians to some extent but not of Blacks (Charles 2003). In Canada, both Asians and Blacks do not seem to adhere to this process of residential integration in contrast to European groups (Fong and Wilkes 1999) although a more recent study using micro-data revealed that spatial assimilation was supported among Blacks and South Asians in Toronto but not for the Chinese (Myles and Hou 2004). The selective applicability of this perspective argues for alternate ways of thinking about residential mobility.

By neglecting the structural factors and conditions that constrain residential options, the assimilation model falls short in accounting for the position of ethnic and racial minorities. Persistent residential concentration of Blacks 
provides support for the place stratification model or the model of a racial hierarchy (Charles 2003; Heisler 1992). The racialized nature of social organization in the US has lead to continued residential segregation and differential spatial outcomes along racial and ethnic lines. In the place stratification model, discrepancies in residential attainment are engendered by a racial structure in which the dominant group maintains social distance through spatial distance in spite of socio-economic gains on the part of minority groups. According to this approach, an uneven spatial distribution results from discrimination by real estate agents, developers and vendors, and from the avoidance behaviour of local residents, who restrict the ability of members of a minority group to convert individual and household achievements into movement out of concentrated neighbourhoods. This perspective argues that integration patterns are not the same for all racial groups, or "panethnic" groups (in recognition of the diversity of ethnic groups contained within racial labels).

Both these perspectives share a fundamental premise that assumes group members use socio-economic resources as a way out of ethnic neighbourhoods, leading to lower segregation levels. The difference lies in the predicted outcome and explanatory mechanisms; spatial assimilation theory argues increased SES will increase integration due to the adoption of host country orientations and behaviours, and place stratification theory asserts that increased SES will not decrease segregation due to systemic discrimination and residentially endogenous preferences by Whites, a process determined by the position of the racial group. Yet, the experience of particular groups provides further evidence contrary to both spatial assimilation and place stratification perspectives, as segregation endures despite high levels of socio-economic attainment and dominant racial group membership (Balakrishnan and Hou 1999; Kalbach 1990; Logan, Alba and Zhang 2002) and through the voluntary separation of minority groups (Lacy 2004). This evidence suggests that for some groups neither of these explanations may be adequate.

A third path of residential incorporation focuses on in-group preferences. The rise in exogenous group contact in some spheres, such as the workplace, may contribute to the effect of increasing or enduring group distinctiveness in others, such as in neighbourhoods. For example, Balakrishnan and Hou (1999) found that despite increasing occupational integration over time, residential segregation persisted. This is consistent with the ethnic retention perspective, which recognizes that assimilation or incorporation can occur along some dimensions without diminishing the relevance of ethnicity (Breton et al. 1990). Acting as a centripetal force, ethnic neighbourhoods offer communities a way to maintain and reproduce ethnic networks, identities and values. They are perceived to be a social good that carries group solidarity and identity, and to provide cultural capital to locally situated group members. Ethnicity operates 
here as an affective tie that draws co-ethnic members into a shared residential location even into second and subsequent generations. In this case, there is a premium on living in the ethnic neighbourhood and ethnic preferences for retaining groupness and culture can promote residential distinctiveness and a pluralistic residential pattern. This perspective argues that ethnic resources can also be a way to preserve residential distinctiveness.

The multiple paths of integration, namely assimilation, stratification and retention, suggest that the integration process is, for the most part, specific to groups. However, the interaction of a social group with its host environment suggests that the same group may adapt differently in another environment. Structural conditions facilitate or hinder residential concentration by circumscribing opportunities for settlement. The urban ecological perspective provides a framework for understanding how urban structure and organization plays a role in creating unique spatial layouts across cities and this has been demonstrated (Farley and Frey 1994; Fong and Wilkes 2003; Massey and Denton 1987; White, Fong and Cai 2003; White and Glick 1999). Furthermore, the distinctive institutional and ideological context that exists at the national level argues for a cross-national approach in studying ethnic integration.

The proximity of Canada and the US in geography and experience provides the opportunity for comparative work between the two places. Both countries are highly urbanized, predominantly English-speaking countries characterized by a history of European settlement, capitalist market economies, democratic political systems and meritocratic ideals, and marked by religious, cultural, regional, class and ethnic and racial heterogeneity. They also repealed nationalorigins provisions in their respective immigration policies in the 1960's, and as a result, permitted large inflows of non-European immigrants.

Despite these commonalities, the two host societies also differ in significant ways. The growing literature on host societies demonstrates that pre-existing ethnic and race relations set the stage for immigrant adjustment as it frames social interaction and affects the orientation of newcomers (Reitz 2003). The prominent history of Black slavery and of legitimized racial segregation in the US contribute to a society where race is a key stratifying feature of the American landscape, potentially more so than in Canada (although Canada has its own history of racial oppression and slavery, see Winks (1971)). This is reinforced by the stronger presence of Blacks, in demographic terms, in the United States and in its dominant urban centres. Canada's Blacks have a relatively small presence comprising approximately 2 percent of the national population compared with an Asian population of 9 percent. The heightened awareness of racial polarization in the US context suggests that we are likely to 
observe larger gaps between panethnic groupings than in Canada, especially between Black and White ethnic groups.

In addition to the racial and ethnic structure, the ideology of ethnic integration provides a set of values and beliefs about intergroup contact. Through national symbols, integration policies and programs, and official statements, states promote normative expectations for group interaction and behaviour. While Canada and the United States are both characterized by liberal citizenship regimes, they differ in the degree to which they believe in the right of ethnic groups to maintain a collective identity and institutions, and to which this right is backed by the state. The position on group rights is stronger in Canada with its bi-cultural colonial history and the Canadian Multiculturalism Act of 1988 that states,

"the Government of Canada recognizes the diversity of Canadians as regards race, national or ethnic origin, colour and religion as a fundamental characteristic of Canadian society and is committed to a policy of multiculturalism designed to preserve and enhance the multicultural heritage of Canadians while working to achieve the equality of all Canadians in the economic, social, cultural and political life of Canada."

In contrast, the US has been characterized as promoting the melting pot ideal of assimilation, fostered by the belief that ethnic distinctions should disappear over time and that newcomers should renounce their old loyalties in order to become "American." The US coat of arms, also demonstrates this ideal stating in Latin, "From many, one" and popular media portrayals of immigration and immigrants are a contemporary bulwark for this national canon (Chavez 2001). In Canada, four countries are represented on the coat of arms, England, Scotland, Ireland and France. The mosaic image makes reference to the idea that ethnic groups maintain some degree of ethnic distinctiveness and that they can adopt a new national identity without shedding their old one. Both of these images are contested in each country yet continue to be promoted through state institutions and national symbols.

Given these cross-national differences, ethnic groups in Canada are not only more likely to be less residentially segregated than comparable groups in the United States, they should also be more likely to follow a pattern of ethnic retention in their residential patterns. However, patterns are expected to vary according to the panethnic grouping. In the data analysis, the objective is to see whether panethnic differences in ethnic residential patterns can be discerned as well as nation-specific experiences. Our theories and empirical findings suggest 
Ann H. Kim

that the processes of residential sorting should vary by national context and by group.

\section{Data and Methods}

The most recent censuses of Canada and the United States provide data for the analysis. Tabulations at the Census Metropolitan Area (CMA) and census tract levels from the 2001 Census of Canada were obtained as well as comparable US data at the metropolitan (Metropolitan Statistical Areas/Consolidated Metropolitan Statistical Areas (MSA/CMSA)) and census tract levels from the 2000 US Census Summary Files 1, 3 and 4.

Initially, a list of the top 25 places of birth for the foreign-born population in each country was derived to ensure that ethnic groupings consisted of substantial numbers of immigrants. From this list, immigrant groups that appeared on both lists were selected, yielding 14 groups. Their corresponding ethnic groups, English, German, Italian, Polish, Russian, Iranian, Chinese, Filipino, Vietnamese, Korean, Asian/East Indian, Pakistani, Jamaican and Haitian, are used to compare residential processes across the two countries.

For both countries, the focus is on the residential patterns of the fourteen ethnic groups in metropolitan areas. Due to the small population or non-existence of particular ethnic groups in some places and to the sensitivity of segregation measures to small numbers, a minimum threshold is applied for inclusion thereby restricting the sample of metropolitan areas. Ethnic groups consisting of at least 1,000 members in a metropolitan area amounted to 189 groups in 25 Canadian metropolitan areas and 1,718 groups in 275 US metropolitan areas. Not all ethnic groups are present for each metropolitan area included.

\section{Variables}

Ethnic residential segregation. In the context of an immigrant society, integration can occur in a minimum of four different directions (Breton 1964). The mainstream community is the direction that is often suggested by the concept of integration. However, immigrants can also enter the co-ethnic community, a different ethnic community or no community at all (anomie). Furthermore, the integration process is not mutually exclusive and most immigrants are likely to integrate into more than one of these cultural groups. Along any single dimension then, ethnic group members may be more or less integrated with a particular community (Breton et al. 1990). In this study on 
residential patterns, segregation is the dependent variable and defined as living with co-ethnics. Integration then, is defined as living with non co-ethnics.

Following the recommendations of Massey and colleagues (1988; 1996), who found the multidimensional nature of segregation called for the use of multiple indices, two segregation indices - the Index of Dissimilarity and the Isolation Index - are estimated for each ethnic group in each metropolitan area in the sample using census tract tabulations. The Index of Dissimilarity is used most often in the two-group case, where values are interpreted as the proportion of a group that must be redistributed in order to obtain the same geographic distribution as the reference group. This index is commonly applied to studies of residential segregation and has now become the true "workhorse" of segregation indices, especially in the literature on ethnic and racial residential segregation (White 1986). The Isolation Index, a measure of residential exposure, captures the probability that two randomly selected people sharing the same neighbourhood will be from the same ethnic group. The isolation value gives the ethnic group proportion of a neighbourhood for the average group member.

The mathematical operations for each segregation measure are as follows:

For the Dissimilarity Index:

$$
D=\frac{1}{2}\left|\sum_{i=1}^{I} \frac{n_{1}}{N_{1}}-\frac{n_{2}}{N_{2}}\right|
$$

where $n_{1}$ is size of group 1 in tract $i$;

$\mathrm{n}_{2}$ is size of all others in tract $\mathrm{i}$;

$\mathrm{N}_{1}$ is total size of group 1in the metropolitan area;

$\mathrm{N}_{2}$ is total size of all others in the metropolitan area.

For the Isolation Index:

$$
{ }_{x} P_{x}^{*}=\sum_{i=1}^{I}\left(\left(\frac{n_{1}}{N_{1}}\right) *\left(\frac{n_{1}}{n_{i}}\right)\right)
$$

where $n_{1}$ is size of group 1 in tract $i$;

$n_{i}$ is size of tract $i$;

$\mathrm{N}_{1}$ is total size of group 1 in the metropolitan area.

Both indices are frequently applied in the segregation literature and they each have the advantage of having a straightforward interpretation. Moreover, they measure two different dimensions of segregation allowing us to identify how residential processes might differ by dimension. ${ }^{1}$ In the statistical analysis, the logit values of these two indices are applied due to their bounded nature 
Ann H. Kim

(between 0 and 1) and to ensure that predicted segregation statistics fall within range.

Ethnic resources. The key explanatory concept includes what is referred to in the ethnic economies literature as ethnic resources and class resources. The former refers to the social features that are particular to an ethnic group and includes the values, attitudes, solidarity and institutions while the concept of class resources refers to both cultural and material resources and includes human capital and economic class values (Light and Bonacich 1988; Light and Gold 2000). Together, these concepts identify the importance of cultural, political, social and economic capital among community members for distinctive patterns of integration. Whereas Light and Bonacich (1988) distinguish between the two types of resources, the term is used as an umbrella label to capture the ethnic link in those resources while recognizing the multidimensional nature of this concept.

This multidimensional view of ethnic resources coupled with the availability of numerous indicators in the data permit the application of a data reduction technique, principal components analysis. The advantage of this technique lies in its ability to linearize an assortment of variables into a few key factors taking into account correlations between variables. Where there are multiple indicators that are highly correlated and that potentially reflect the same underlying concept, it can be an appropriate method for dealing with problems of collinearity in the model. Moreover, it allows for the inclusion of multiple indicators into an index rather than limiting the researcher to the selection of one or two variables.

Ethnic resource variables are measured at the metropolitan level for each ethnic group represented and include seven indicators: proportion older adults, proportion foreign-born, proportion speaking no official language(s), proportion of foreign-born arriving within previous 10 years, proportion with a university degree, proportion unemployed and median male income (in US\$). ${ }^{2}$ Using these seven variables and a varimax (or orthogonal) rotation ${ }^{3}$, the Kaiser criterion (Eigenvalues greater than 1.0) gives two independent factors and taken together they explain 60 percent of the variance. (Results are not shown but are available upon request.)

Based on the scoring coefficients, the two factors can be labelled acculturation and socio-economic status (Table 1). The three variables with higher scores on the first factor are proportion older adults, proportion foreign-born and proportion speaking no official language(s). This factor is multiplied by -1 so that ethnic groups scoring high on this factor are more likely to be acculturated 
Panethnicity and Ethnic Resources in Residential Integration:

A Comparative Study of Two Host Societies

Table 1

Measurement of Explanatory Variables

\begin{tabular}{|c|c|c|}
\hline \multirow{2}{*}{ Variables } & \multicolumn{2}{|c|}{ Measurement } \\
\hline & Canada & United States \\
\hline \multicolumn{3}{|c|}{ Ethnic Group Characteristics } \\
\hline Group Size & $\begin{array}{l}\text { Single ethnic origin } \\
\text { Natural log }\end{array}$ & $\begin{array}{l}\text { First ancestry/Asian alone } \\
\text { Natural } \log \end{array}$ \\
\hline Self-employment & $\begin{array}{l}\text { Proportion self-employed } \\
15+\text { years in labour force }\end{array}$ & $\begin{array}{l}\text { Proportion self-employed } \\
16+\text { years in labour force }\end{array}$ \\
\hline Acculturation & \multicolumn{2}{|c|}{$\begin{array}{c}-.27[\% \text { older adults }]+.34[\% \text { foreign born }] \\
+.31[\text { lack official language }]+.17[\% \text { newcomers }] \\
+.08[\% \text { university degree }] \\
-.21[\text { median male income USD }]+.19[\% \text { unemployed }]\end{array}$} \\
\hline $\begin{array}{l}\text { Socioeconomic } \\
\text { status }\end{array}$ & \multicolumn{2}{|c|}{$\begin{array}{c}-.07[\% \text { older adults]-.06[\% foreign born }] \\
-.05[\text { lack official language }]+.31[\% \text { newcomers }] \\
+.5[\% \text { university degree }] \\
+.41[\text { median male income USD]-.27[\% unemployed }]\end{array}$} \\
\hline \multicolumn{3}{|l|}{ Panethnicity } \\
\hline White & \multicolumn{2}{|c|}{$\begin{array}{l}\text { English, German, Italian, Polish, Russian, Iranian=1; } \\
0 \text { otherwise }\end{array}$} \\
\hline Black & \multicolumn{2}{|c|}{ Jamaican, Haitian $=1 ; 0$ otherwise } \\
\hline Asian & \multicolumn{2}{|c|}{$\begin{array}{l}\text { Indian, Pakistani, Chinese, Vietnamese, Korean, } \\
\text { Filipino }=1 ; 0 \text { otherwise }\end{array}$} \\
\hline \multicolumn{3}{|c|}{ Metropolitan Context } \\
\hline Population size & Natural log & Natural log \\
\hline New housing & $\begin{array}{l}\text { Proportion of homes } \\
\text { Constructed from } 1996 \text { to } \\
2001\end{array}$ & $\begin{array}{l}\text { Proportion of homes } \\
\text { Constructed from } 1996 \text { to } \\
2001\end{array}$ \\
\hline Home ownership & Proportion owner-occupied & Proportion owner-occupied \\
\hline
\end{tabular}


Ann H. Kim

\section{Table 1 \\ Measurement of Explanatory Variables (continued)}

Industry Base

Region
Dummy variable if greater than 1 standard deviation above mean for all metro areas, then summed across industries $0=$ if metro area is not above 1 SD for any industry $1=$ if metro area is above 1 SD for 1 industry $2=$ if metro area is above 1 SD for 2 industries $3=$ if metro area is above 1 SD for 3 or more industries Industries include agriculture/mining, transportation/utilities, construction, manufacturing, wholesale/trade, retail trade, information, financial/real estate, $\mathrm{professional} / \mathrm{management}$, education/health, arts/food services, other services, public administration

$\begin{array}{ll}\text { Ontario } & \text { West } \\ \text { Quebec } & \text { Midwest } \\ \text { West } & \text { Northeast } \\ \text { East } & \text { South }\end{array}$

as they have an older age structure, are more native-born and have higher levels of official language acquisition. The mean score on acculturation for the US sample is .19 and -.14 for the Canadian sample (Table 2). This should be expected given the greater share of immigrants in Canada's population as compared with the United States.

The second factor weighs more heavily on socio-economic indicators such as the median income of males, proportion of individuals with a university degree, and the unemployment rate (Table 1). A fourth indicator, that of proportion newcomers, is also a stronger indicator of SES than acculturation. Given that newcomers are still settling into the economic system and are likely to fall towards the lower end of the occupational ladder, it is reasonable to think that ethnic groups with higher proportions of newcomers are also those with lower levels of SES. Again, the Canadian sample, on average, falls below the US sample on the SES factor score with -.64. The US score is .002.

On theoretical and methodological grounds, group size and proportion selfemployed remain included in the models as separate variables (Table 1). Group size acts as a resource for members such that larger groups not only have greater 
visibility and presence but also have a population base for accessing other kinds of resources. The population size of ethnic groups has also been known to influence residential segregation statistics, generally in a negative direction. The natural $\log$ of group size is used in the multivariate models and the descriptive statistics in Table 2 show that US ethnic groups are generally larger than Canadian ones.

The self-employment rate could also have a unique association with residential patterns although this is often perceived to be an effect of residential concentration and not a determinant (Waldinger, McEvoy and Aldrich 1990). Nevertheless, as a potential source for social mobility, its effect on residential patterns may be an important aspect of ethnic integration. On this trait, Canadian ethnic groups in the sample tend to have higher rates of self-employment (Table 2).

All ethnic resource variables are measured at the aggregate level, for ethnic groups in metropolitan areas. The model then provides a test of which resources at a group level are associated with residential integration. The results of this ecological model preclude making inferences regarding the individual behaviour of group members but they allow us to observe the effect of differences in group level factors.

Panethnic grouping. The development of panethnic and racial labels reflects a shift in ethnic group identities to a broader level (Espiritu 1992). This occurs through a process of racialization where a collectivity of national origin or ancestry groups is perceived to share similar features such as language or phenotype. The place stratification hypothesis provides a further argument for the importance of this variable in explaining residential patterns and suggests that residential processes vary by panethnicity or race making it a key interacting variable. In the models, I interact panethnicity with the two extracted ethnic resource factors, acculturation and socio-economic status. In the pooled model, this is also interacted with the country variable as levels of residential segregation are expected to vary according to panethnicity across the two countries.

The sample is allocated into one of three panethnic groups, White, Black or Asian and the coding of ethnic groups is provided in Table 1. As Table 2 shows, White ethnic groups comprise the majority followed by Asian and Black ethnic groups in both samples.

Urban and regional context. The urban ecological framework argues that the urban setting plays a role in shaping population distribution (Farley and Frey 1994; Fong and Wilkes 2003; Massey and Denton 1987; White, Fong and Cai 
Ann H. Kim

2003). For this reason, four indicators at the metropolitan level are used as control variables: population size (logged), proportion of new housing construction in the decade prior to the census, proportion of owner-occupied homes, and industry base (Table 1). ${ }^{4}$ In addition, control is made for region with four in the US and four in Canada. These are listed in Table 1.

\section{Panethnic Patterns of Residential Segregation}

When residential segregation values for ethnic origin or ancestry groups are aggregated by panethnic grouping and compared across countries using a pooled sample, group and country differences emerge in the bivariate analysis. While White and Asian ethnic groups are, on average, similarly segregated across countries using the Dissimilarity Index (although values are slightly higher in Canada), Black ethnic groups are significantly more segregated in the United States than comparable groups in Canada. For Whites, mean segregation values are .26 for the US and .3 for Canada and for Asians, values are .48 and .54 , respectively. US Blacks in the sample register a Dissimilarity Index of .7 and in Canada, they obtain an index of .54.

Greater variation can be observed for groups measured on the Isolation Index with values of .07 and .05 for Whites in the US and Canada, respectively, .03 and .02 for Blacks, respectively, and .02 and .05 for Asians, respectively. The two indices give two different stories of residential segregation. This is not surprising since they are separate dimensions of segregation but also because the Isolation Index is more sensitive to group proportion in the city. Moreover, these values do not control for group factors or the metropolitan context and when a multivariate model is tested using the pooled sample (Pooled column, Table 3), the two indices reveal somewhat similar patterns of significant panethnic effects.

Converting logits back to their original scale and controlling for covariates ${ }^{5}$, White ethnic groups in the two countries are at similar levels of residential segregation (Dissimilarity value of .37 and Isolation value of .02). In contrast, Asian ethnic groups continue have a higher level of segregation in Canada than in the US on both indices $\left(D=.32, .44,{ }_{x} P_{x}=.018, .022\right.$, US and Canada, respectively). Black ethnic groups reveal the opposite pattern with higher levels of segregation in the US than in Canada $\left(D=.56, .42,{ }_{x} P_{x}=.05, .03\right.$, US and Canada, respectively). As predicted, differences between groups are larger in the US context than in Canada, especially between Blacks and the other two groups. These results demonstrate that the national context is important for the effect of panethnic grouping on residential patterns. 
Panethnicity and Ethnic Resources in Residential Integration:

A Comparative Study of Two Host Societies

Table 2

Descriptive Statistics for Multivariate Analysis

\begin{tabular}{|c|c|c|}
\hline Variables & United States & Canada \\
\hline & \multicolumn{2}{|c|}{ mean/prop. (std. dev) } \\
\hline \multicolumn{3}{|l|}{ Dependent variables } \\
\hline Dissimilarity Index (logit) & $-.76(.8)$ & $-.40(.9)$ \\
\hline Isolation Index (logit) & $-3.40(1.2)$ & $-3.52(1.0)$ \\
\hline \multicolumn{3}{|l|}{ Ethnic resources } \\
\hline Acculturation & $.19(1.0)$ & $-.14(1.2)$ \\
\hline Socioeconomic status & $.002(.9)$ & $-.64(.7)$ \\
\hline Group size (logged) & $9.1(1.5)$ & $8.9(1.4)$ \\
\hline Self-employment & $.10(.04)$ & $.12(.07)$ \\
\hline \multicolumn{3}{|l|}{ Panethnicity } \\
\hline White & $.69(.5)$ & $.52(.5)$ \\
\hline Black & $.04(.2)$ & $.07(.3)$ \\
\hline Asian & $.28(.4)$ & $.41(.5)$ \\
\hline \multicolumn{3}{|l|}{ Metropolitan context } \\
\hline Population size (logged) & $14.4(27.9)$ & $11.4(12.9)$ \\
\hline Home ownership & $.66(.06)$ & $.65(.06)$ \\
\hline New housing & $.10(.05)$ & $.07(.03)$ \\
\hline Industry (3 or more) & $.25(.4)$ & $.32(.5)$ \\
\hline 0 & $.11(.3)$ & -- \\
\hline 1 & $.36(.5)$ & $.30(.5)$ \\
\hline 2 & $.28(.5)$ & $.38(.5)$ \\
\hline \multicolumn{3}{|l|}{ US Regions } \\
\hline West & $.21(.4)$ & $\mathrm{n} / \mathrm{a}$ \\
\hline Midwest & $.24(.4)$ & $\mathrm{n} / \mathrm{a}$ \\
\hline Northeast & $.15(.4)$ & $\mathrm{n} / \mathrm{a}$ \\
\hline South & $.41(.5)$ & $\mathrm{n} / \mathrm{a}$ \\
\hline \multicolumn{3}{|l|}{ Regions in Canada } \\
\hline Ontario & $\mathrm{n} / \mathrm{a}$ & $.49(.5)$ \\
\hline Quebec & $\mathrm{n} / \mathrm{a}$ & $.10(.3)$ \\
\hline BC \& Prairies & $\mathrm{n} / \mathrm{a}$ & $.37(.5)$ \\
\hline Maritimes & $\mathrm{n} / \mathrm{a}$ & $.04(.2)$ \\
\hline
\end{tabular}


Ann H. Kim

\section{Paths to Residential Incorporation}

Using the aggregate data described in Table 2, OLS regression of ethnic residential integration is also employed for each of the logits of Dissimilarity $(l(D))$ and Isolation $\left(l\left({ }_{x} P_{x}\right)\right)$ on the interaction of acculturation and socioeconomic resources with panethnic grouping, and on other explanatory variables including group size and self-employment, controlling for the urban context and region for each of the two countries separately (Table 3). Focus is on how acculturation and socio-economic resources impact on levels of residential segregation by panethnic grouping.

Studies of residential processes have shown that resources may operate in different ways for different groups suggesting that panethnicity or race should have an interacting effect with resources on integration (Alba and Logan 1993; Fong and Gulia 1999; Massey and Denton 1987; White and Sassler 2000). The coefficients of acculturation by panethnic grouping in both country-specific columns of Table 3 reveals that acculturation has an integrating effect for all groups in both countries, albeit for some the effect is negligible. With increasing levels of acculturation, residential segregation can be expected to decline to some extent for most groups, net of covariates. In Canada, the effect is greatest for White ethnic groups than for the other two panethnic groupings and in the US for Asian ethnic groups.

Figure 1 illustrates panethnic and country patterns visually. Along the horizontal axis of each graph is the acculturation score (which does not have any inherent meaning other than that higher values indicate higher levels of acculturation) and the vertical axis depicts the segregation index converted back from the logit transformation. Holding other covariates constant, we can observe the effect of acculturation by panethnic group and country on the two indices.

The lines in the two graphs provide evidence of cross-national differences by panethnicity in the effect of acculturation on ethnic residential integration; White ethnic groups in Canada experience a greater decline in residential segregation for every unit increase in acculturation than comparable groups in the US; Black and Asian ethnic groups in the US experience a greater decline in segregation for every unit increase in acculturation than comparable groups in Canada, although for Asians in Canada this effect is negligible. ${ }^{6}$ These patterns are similar across both segregation indices. 
Panethnicity and Ethnic Resources in Residential Integration:

A Comparative Study of Two Host Societies

Table 3

Regression Analysis on Residential Integration

\begin{tabular}{|c|c|c|c|c|c|c|}
\hline \multirow{2}{*}{ Ethnic Resources } & \multicolumn{2}{|c|}{ Canada } & \multicolumn{2}{|c|}{ United States } & \multicolumn{2}{|c|}{ Pooled } \\
\hline & & & & & & \\
\hline Acculturation & $-.339 * *$ & $-.256 * *$ & $-.113 * *$ & $-.179 * *$ & $-.150 * *$ & $-.191 * *$ \\
\hline Socioeconomic status & -.024 & -.087 & $.179 * *$ & $.099 * *$ & $.167 * *$ & $.090 * *$ \\
\hline Group size (logged) & $-.263 * *$ & $.866 * *$ & $-.278 * *$ & $.895 * *$ & $-.280 * *$ & $.889 * *$ \\
\hline Self-employment & -.120 & -.232 & .137 & $.580 * *$ & .094 & .214 \\
\hline Panethnicity (White) & -- & -- & -- & - & -- & -- \\
\hline Black & .271 & .047 & $.842 * *$ & $.935 * *$ & $.789 * *$ & $.833 * *$ \\
\hline Asian & $.486 * *$ & $.217 * *$ & $-.266 * *$ & $-.253 * *$ & $-.240 * *$ & $-.231 * *$ \\
\hline \multicolumn{7}{|l|}{ Metropolitan context } \\
\hline Population size (logged) & $.395 * *$ & $-.747 * *$ & $.425 * *$ & $-.786 * *$ & $.431 * *$ & $-.775^{* *}$ \\
\hline Home ownership & -.352 & -.006 & $-.559 * *$ & -.008 & $-.499 * *$ & -.057 \\
\hline New housing & -1.430 & -1.394 & $-1.717 * *$ & $-1.505 * *$ & $-1.082 * *$ & $-1.493 * *$ \\
\hline Industry ( 3 or more) & -- & -- & -- & -- & -- & -- \\
\hline 0 & $\mathrm{n} / \mathrm{a}$ & $\mathrm{n} / \mathrm{a}$ & .011 & .0005 & -.003 & -.001 \\
\hline 1 & -.060 & -.081 & $.076^{* *}$ & -.005 & $.062 * *$ & .001 \\
\hline 2 & -.091 & -.049 & $.066^{* *}$ & -.020 & $.044 *$ & .020 \\
\hline Region (West) & -- & -- & -- & -- & -- & -- \\
\hline Midwest & -- & -- & .015 & $.066 * *$ & -- & -- \\
\hline Northeast & -- & -- & -.021 & .012 & -- & -- \\
\hline South & -- & -- & $.144 * *$ & $.051 * *$ & -- & -- \\
\hline Region (Ontario) & -- & -- & -- & -- & -- & -- \\
\hline Quebec & $.325 * *$ & $.370 * *$ & -- & -- & -- & -- \\
\hline BC \& Prairies & -.039 & -.042 & -- & -- & -- & -- \\
\hline Maritimes & -.213 & .022 & -- & -- & -- & -- \\
\hline \multicolumn{7}{|l|}{ Interactions } \\
\hline Acculturation* Black & .138 & .245 & -.141 & $-.186 * *$ & -.097 & $-.154 *$ \\
\hline Acculturation* Asian & $.275 * *$ & $.150 * *$ & $-.296 * *$ & $-.328 * *$ & $-.240 * *$ & $-.274 * *$ \\
\hline SES* Black & .008 & -.054 & $-.210 * *$ & .079 & $-.230 * *$ & .027 \\
\hline SES* Asian & $-.165^{*}$ & $-.140 *$ & $-.107 * *$ & -.005 & $-.119 * *$ & -.018 \\
\hline Canada & -- & -- & - & - & .004 & .031 \\
\hline Canada* Black & -- & - & - & -- & $-.570 * *$ & $-.524 * *$ \\
\hline Canada* Asian & -- & -- & -- & -- & $.524 * *$ & $.157 * *$ \\
\hline
\end{tabular}

Unstandardized coefficients

$* \mathrm{p}<.1$

$* * \mathrm{p}<.05$ 
The first four columns of Table 3 also show that the effect of socio-economic resources depends, to some extent, on the panethnic grouping to which the ethnic group belongs for each of the two host societies. For White ethnic groups in Canada, socio-economic status appears to have no statistically significant effect on both indices of segregation. Black ethnic groups appear to be similar to Whites but Asians follow a pattern of integration. Results for the US show that, net of covariates, higher socio-economic scores are positively associated with segregation levels for White ethnic groups. The effects for the other two groups are different only in terms of the Dissimilarity Index. For the Isolation Index, no including group size and self-employment, controlling for the urban context and region for each of the two countries separately (Table 3). Focus is on how acculturation and socio-economic resources impact on levels of residential segregation by panethnic grouping.

Figure 2 allows us to observe these associations by panethnicity and country more clearly. In the two panels, socio-economic factor scores are listed along the $\mathrm{x}$-axis, segregation indices are converted back to their original scales on the $\mathrm{y}$ axis and covariates are held constant. As with acculturation, these values have no meaningful interpretation other than direction; higher values indicate higher levels of socio-economic resources such as income and education. The two panels reveal no obvious cross-national pattern. Rather, cross-national differences are by panethnic grouping. Socio-economic resources do not have an effect on residential segregation for White ethnic groups in Canada, net of covariates, but SES does appear to be a means for increasing separation for comparable groups in the United States. For Asians in Canada, SES is associated with declining residential segregation but has the opposite effect for the same group in the US. Identifying the segregation dimension is important when comparing Black ethnic groups across both countries. In terms of Dissimilarity, Black ethnic groups show similar patterns, with flat slopes across SES scores. However, the net effect of socio-economic resources on the Isolation Index diverges for this panethnic group, with a slight negative slope in Canada and a positive slope (i.e. increasing segregation) in the US. The results illustrate that, for the most part, the effect of socio-economic resources is not only dependent on panethnic group membership but also on the host society. 
Panethnicity and Ethnic Resources in Residential Integration:

A Comparative Study of Two Host Societies

Figure 1. Acculturation

A. Net Effect of Acculturation Scores on Dissimilarity

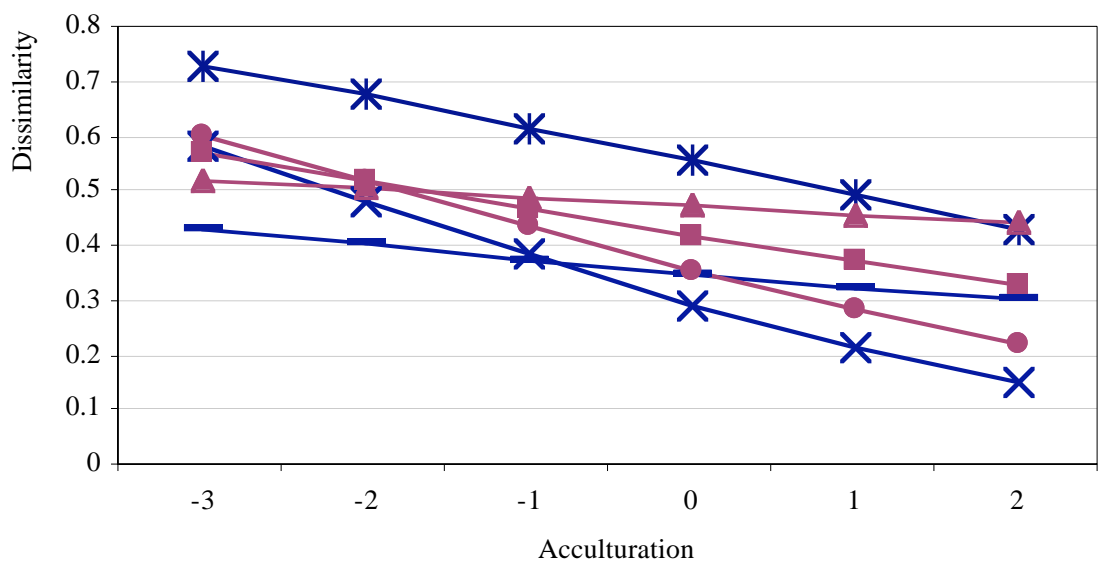

B. Net Effect of Acculturation Scores on Isolation
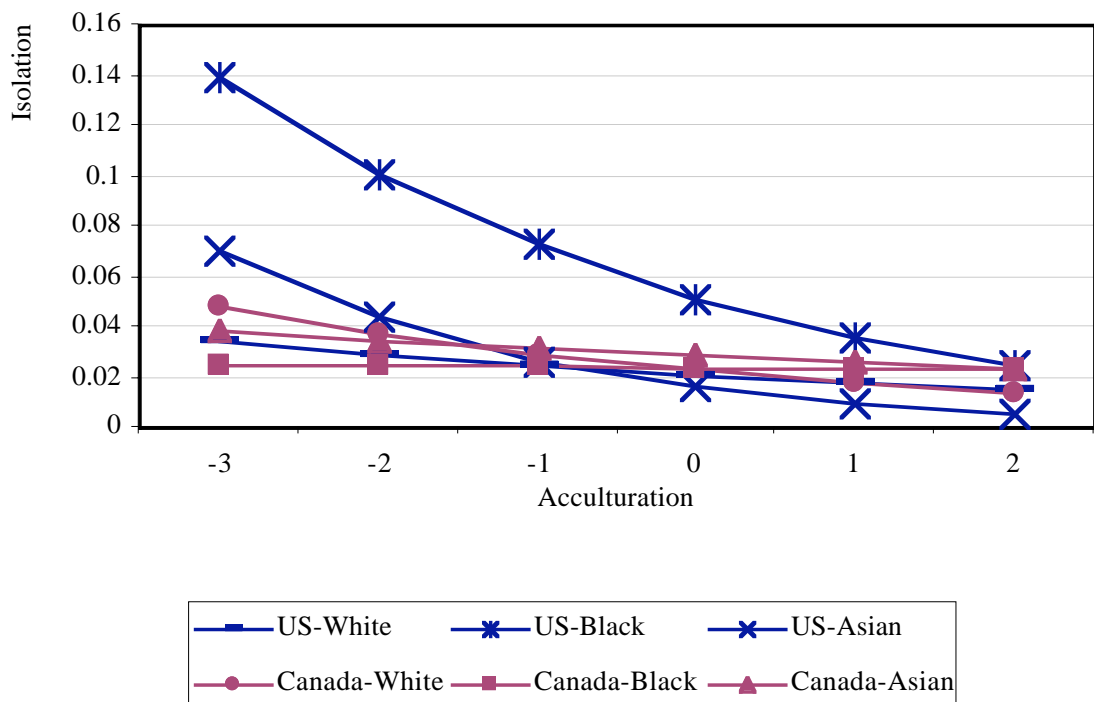
Ann H. Kim

Figure 2. Socio-economic Resources

\section{A. Net Effect of Socio-economic Scores on Dissimilarity}

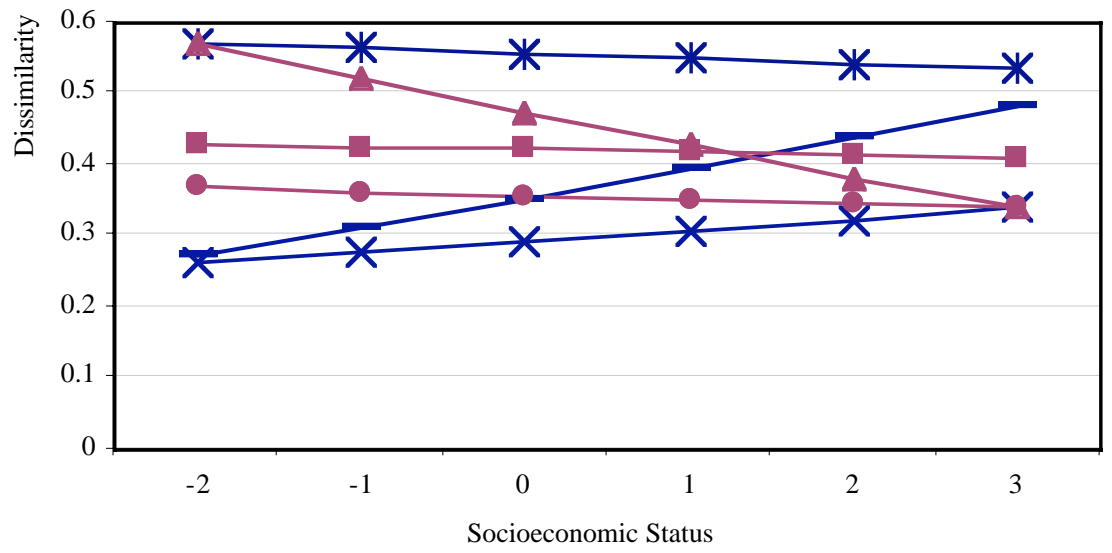

\section{B. Net Effect of Socio-economic Scores on Isolation}

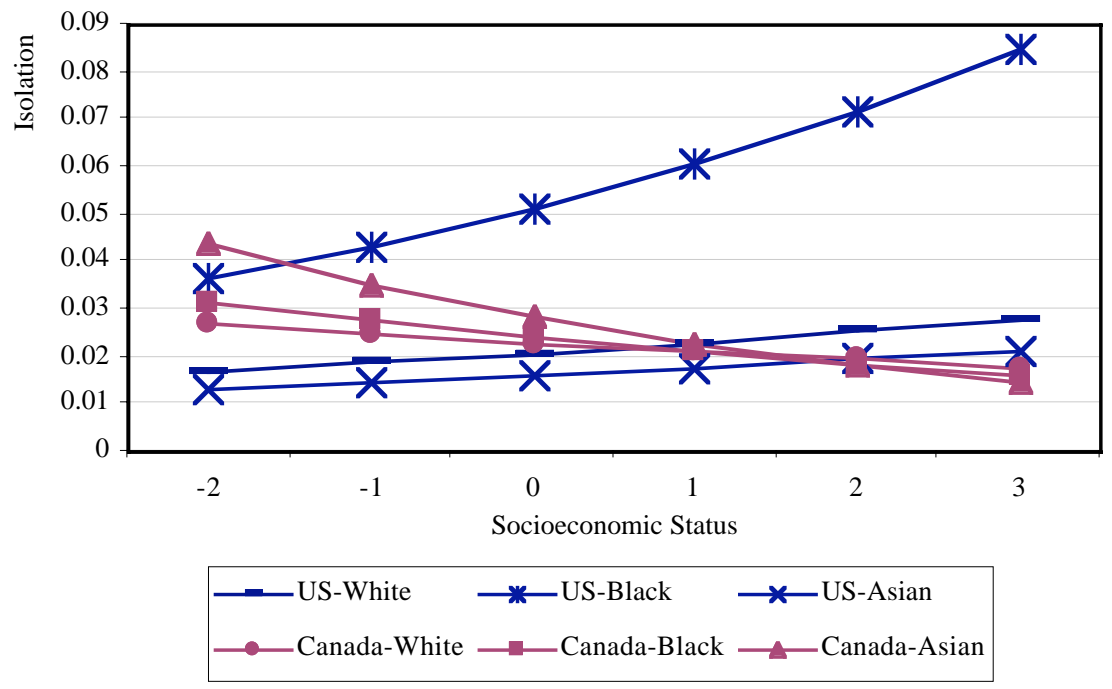


Remaining ethnic group variables indicate that group size has a significant negative effect on residential evenness $(l(D))$, net of covariates, and the opposite effect on residential isolation $\left(l\left({ }_{x} P_{x}\right)\right)$. This is expected as these measurements can be sensitive to group size. The multivariate test also shows that selfemployment is not a consistent predictor of residential separation. Having a high group self-employment rate is not likely to lead to residential segregation in Canada but may do so in the United States, suggesting that context has some part to play in structuring the opportunities that self-employment provides.

\section{Discussion and Conclusions}

The objective of this study was to investigate the importance of context on ethnic residential integration. By classifying each of 14 ethnic groups into one of three panethnic groupings, panethnic group membership was tested on how it interacts with group resources to effect residential segregation, as measured by two preferred indices of segregation. The results demonstrate that the national context plays a significant role in the way panethnic group membershiinfluences the spatial distribution of ethnic groups in the urban neighbourhoods of Canada and the US.

Two ways in which the context is important can be identified. First, for how groups are distributed across urban neighbourhoods. After controlling for group resources, metropolitan and regional context, differences in the levels of segregation between panethnic groupings remained. As expected, the gap between the three groupings were smaller in Canada than in the US supporting findings in previous studies (Fong 1996). Moreover, cross-national differences by panethnicity emerged for Black and Asian ethnic groups. Blacks were more segregated in the US than comparable groups in Canada and Asians were more segregated in Canada than comparable groups in the US. White ethnic groups in both countries were similarly segregated, which may be explained by their dominant status in both countries.

Second, there are cross-national differences in the way ethnic resources impact on ethnic residential segregation and these differences depend on panethnic boundaries. Three theoretical paths to residential integration were identified and the effects of two dimensions of ethnic resources were assessed. In general, acculturation was found to promote residential integration for most groups to varying degrees, but was not the case for Black and Asian ethnic groups in Canada. The effect of socio-economic resources was more dependent on group and host society. The results show that SES was negatively associated with residential segregation only for Asians in Canada, contradicting expectations that spatial assimilation theory applies to White ethnic groups. In the United 
States, SES appears more likely to "buy" separation, as segregation levels rise with increasing resources for Whites and Asians. This was also found for Blacks in the US but only in terms of the Isolation Index. The data do not permit us to distinguish whether ethnic retention or place stratification is operating on the residential processes of these groups. However, research on residential preferences suggests an interaction of in-group tendencies and social distance are likely to be part of the explanation and that racial stratification is more likely to be operating on US patterns (Adelman 2005; Charles 2003; Fong 1994; Krysan and Farley 2002).

This study showed that the national context has implications for ethnic integration and highlighted some areas for further investigation. Whether it is due to demographic dynamics (i.e. a larger ethnic presence), avoidance on the part of others, or an assertion of ethnicity in an institutional context that supports Asian distinctiveness, an explanation is needed for the higher level of Asian segregation in Canada in comparison to Asians in the US. The extent to which persistent segregation is the result of in-group preference and out-group avoidance can also be further clarified. In sum, panethnic differences across national borders suggest that the racial and ethnic structure is likely to be key to understanding the residential incorporation process of groups more so than other dimensions such as the ideology of integration.

\section{Acknowledgements:}

An earlier version of this paper was presented at the 2005 Canadian Population Society Meetings, Congress of the Humanities and Social Sciences at the University of Western Ontario. The author would like to acknowledge Michael J. White, Calvin Goldscheider and José Itzigsohn for their intellectual support and guidance on this research. 
Panethnicity and Ethnic Resources in Residential Integration:

A Comparative Study of Two Host Societies

\section{End Notes:}

1. The two dimensions are not completely independent. In these data, they are somewhat correlated with a correlation coefficient of -..42.

2. For groups in Canada, income was converted to US dollars using the 2001 annual average exchange rate from the Bank of Canada.

3. An oblique rotation using promax(3) showed a very low correlation between factors $(\mathrm{r}=.0001)$.

4. The percent foreign-born and non-white were omitted from the analysis due to multicollinearity. Both variables have a significant, positive effect on segregation in the bivariate analysis (with the exception of Isolation in the US sample) but with the inclusion of metropolitan population size in the multivariate model, they lose their predictive power.

5. Values for covariates are held constant: metropolitan population 1,000,000 (logged), homeownership .65, new housing construction .10, 2 industries, West region in the US, Ontario in Canada, group size 10,000 (logged), self-employment .10, acculturation score 0 , socioeconomic score 0 .

6. This result should be taken with caution as the small sample size for Blacks in Canada suggests that the coefficient is not likely to be the most consistent estimate. 
Ann H. Kim

\section{References:}

Adelman, Robert M. 2005. "The roles of race, class, and residential preferences in the neighborhood racial composition of middle-class blacks and whites." Social Science Quarterly 86: 209-228.

Alba, Richard D., and John R. Logan. 1993. "Minority proximity to whites in suburbs: An individual-level analysis of segregation." American Journal of Sociology 98: 1388-1427.

Balakrishnan, T.R. 2001. "Residential segregation and socio-economic integration of Asians in Canadian cities." Canadian Ethnic Studies 33: $120-132$.

Balakrishnan, T.R., and Stephen Gyimah. 2003. "Spatial residential patterns of selected ethnic groups: Significance and policy implications." Canadian Ethnic Studies 35: 113-135.

Balakrishnan, T.R., and Feng Hou. 1999. "Socioeconomic integration and spatial residential patterns of immigrant groups in Canada." Population Research and Policy Review 18: 201-217.

Bloemraad, Irene. 2003. "Institutions, ethnic leaders, and the political incorporation of immigrants: A comparison of Canada and the United States." Pp. 361-401 in Host societies and the reception of immigrants, edited by Jeffrey G. Reitz. La Jolla, CA: Center for Comparative Immigration Studies.

Breton, Raymond. 1964. "Institutional completeness of ethnic communities and the personal relations of immigrants." American Journal of Sociology 70: 193-205.

Breton, Raymond, Wsevolod W. Isajiw, Warren E. Kalbach, and Jeffrey G. Reitz (Eds.). 1990. Ethnic identity and equality: Varieties of experience in a Canadian city. Toronto: University of Toronto Press.

Charles, Camille Zubrinsky. 2003. "The dynamics of racial residential segregation." Annual Review of Sociology 29: 167-207.

Chavez, Leo R. 2001. Covering immigration: Popular images and the politics of the nation. Berkeley: University of California Press. 
Panethnicity and Ethnic Resources in Residential Integration:

A Comparative Study of Two Host Societies

Dinardo, John, and Thomas Lemieux. 1997. "Diverging male wage inequality in the United States and Canada, 1981-1988: Do institutions explain the difference?" Industrial and Labor Relations Review 50: 629-651.

Espiritu, Yen Le. 1992. Asian American panethnicity: Bridging institutions and identities. Philadelphia: Temple University Press.

Farley, Reynolds, and William H. Frey. 1994. "Changes in the segregation of whites from blacks during the 1980s: Small steps toward a more integrated society." American Sociological Review 59: 23-45.

Fong, Eric. 1994. "Residential proximity among racial groups in U.S. and Canadian neighborhoods." Urban Affairs Quarterly 30: 285-297.

Fong, Eric. 1996. "A comparative perspective on racial residential segregation: American and Canadian experiences." Sociological Quarterly 37: 199-27.

Fong, Eric, and Milena Gulia. 1999. "Differences in neighborhood qualities among racial and ethnic groups in Canada." Sociological Inquiry 69: 575-598.

Fong, Eric and Rima Wilkes. 1999. "The spatial assimilation model reexamined: An assessment by Canadian data." International Migration Review 33: 594-620.

Fong, Eric and Rima Wilkes. 2003. "Racial and ethnic residential patterns in Canada." Sociological Forum 18: 577-602.

Guest, Avery M., and James A. Weed. 1976. "Ethnic residential segregation: Patterns of change." American Journal of Sociology 81: 1088-1111.

Heisler, Barbara S. 1992. "The future of immigrant incorporation: Which models? Which concepts?" International Migration Review 26: 623-645.

Kalbach, Warren E. 1990. "Ethnic residential segregation and its significance for the individual in an urban setting." Pp. 92-134 in Ethnic identity and equality: Varieties of experience in a Canadian city, edited by Raymond Breton, Wsevolod W. Isajiw, Warren E. Kalbach, and Jeffrey G. Reitz. Toronto: University of Toronto Press. 
Ann H. Kim

Kantrowitz, Nathan. 1973. Ethnic and racial segregation in the New York metropolis: Residential patterns among white ethnic groups, blacks and Puerto Ricans. New York: Praeger Publishers.

Krysan, Maria, and Reynolds Farley. 2002. "The residential preferences of blacks: Do they explain persistent segregation?" Social Forces 80: 937-980.

Lacy, Karyn R. 2004. "Black spaces, black places: Strategic assimilation and identity construction in middle-class suburbia." Ethnic and Racial Studies 27: 908-930.

Lewin-Epstein, Noah, Noshe Semyonov, Irena Kogan, and Richard A. Wanner. 2003. "Institutional structure and immigration integration: A comparative study of immigrants' labor market attainment in Canada and Israel." International Migration Review 37: 389-420.

Lieberson, Stanley. 1963. Ethnic patterns in American cities. New York: The Free Press of Glencoe.

Light, Ivan, and Edna Bonacich. 1988. Immigrant Entrepreneurs. Berkeley: University of California Press.

Light, Ivan Hubert, and Steven J. Gold. 2000. Ethnic economies. San Diego, CA: Academic Press.

Logan, John R., Richard D. Alba, and Wenquan Zhang. 2002. "Immigrant enclaves and ethnic communities in New York and Los Angeles." American Sociological Review 67: 299-322.

Massey, Douglas S, and Brendan P Mullan. 1984. "Processes of Hispanic and Black spatial assimilation." American Journal of Sociology 89: 836-873.

Massey, Douglas S., and Nancy A. Denton. 1987. "Trends in the residential segregation of Blacks, Hispanics, and Asians: 1970-1980." American Sociological Review 52: 802-825.

Massey, Douglas S., and Nancy A. Denton. 1988. "The dimensions of residential segregation." Social Forces 67: 281-315. 
Panethnicity and Ethnic Resources in Residential Integration:

A Comparative Study of Two Host Societies

Massey, Douglas S., Michael J. White, and Voon-Chin Phua. 1996. "The dimensions of segregation revisited." Sociological Methods and Research 25: 172-206.

Model, Suzanne. 1997. "An occupational tale of two cities: Minorities in London and New York." Demography 34: 539-550.

Myles, John, and Feng Hou. 2004. "Changing colours: Spatial assimilation and new racial minority immigrants." Canadian Journal of Sociology 29: 29-58.

Park, Robert E., Ernest W. Burgess, and Roderick D. McKenzie. 1925. The city. Chicago: The University of Chicago Press.

Reitz, Jeffrey G. 1998. Warmth of the welcome: The social causes of economic success in different nations and cities. Boulder, CO: Westview Press.

Reitz, Jeffrey G (Ed.). 2003. Host societies and the reception of immigrants. La Jolla, CA: Center for Comparative Immigration Studies.

Waldinger, Roger, David McEvoy, and Howard Aldrich. 1990. "Spatial dimensions of opportunity structures." Pp. 106-130 in Ethnic entrepreneurs: Immigrant business in industrial societies, edited by Roger Waldinger, Howard Aldrich, Robin Ward, and Associates. Newbury Park, CA: Sage Publications, Inc.

White, Michael J. 1986. "Segregation and diversity measures in population distribution." Population Index 52: 198-221.

White, Michael J., Eric Fong, and Qian Cai. 2003. "The Segregation of AsianOrigin Groups in the United States and Canada." Social Science Research 32: 148-167.

White, Michael J., and Jennifer E. Glick. 1999. "The impact of immigration on residential segregation." Pp. 345-372 in Immigration and opportunity: race, ethnicity, and employment in the United States, edited by Frank D. Bean and Stephanie Bell-Rose. NY: Russell Sage.

White, Michael J., Ann H. Kim, and Jennifer E. Glick. forthcoming. "Mapping social distance: Ethnic residential segregation in a multiethnic metro." Sociological Methods and Research. 
Ann H. Kim

White, Michael J., and Sharon Sassler. 2000. "Judging not only by color: Ethnicity, nativity and neighbourhood attainment." Social Science Quarterly 81: 997-1013.

Winks, Robin W. 1971. The Blacks in Canada: A history. Montréal: McGillQueen's University Press.

Zhou, Min, and John R. Logan. 1991. "In and out of Chinatown: Residential mobility and segregation of New York City's Chinese." Social Forces 7 